\title{
Design and Performance Evaluation of a Solar Assisted Heat Pump Dryer Integrated with Biomass Furnace for Red Chilli
}

\author{
M. Yahya \\ Fakultas Teknologi Industri, Institut Teknologi Padang, Padang, West Sumatra 25132, Indonesia \\ Correspondence should be addressed to M. Yahya; yahya@itp.ac.id
}

Received 20 January 2016; Accepted 7 March 2016

Academic Editor: Daniele Dondi

Copyright ( 2016 M. Yahya. This is an open access article distributed under the Creative Commons Attribution License, which permits unrestricted use, distribution, and reproduction in any medium, provided the original work is properly cited.

\begin{abstract}
The performance of a solar assisted heat pump dryer integrated with biomass furnace has been designed and evaluated for drying red chillies, and drying kinetics of red chillies were evaluated. The red chillies were dried from $22 \mathrm{~kg}$ with moisture content of $4.26 \mathrm{db}$ to moisture content of $0.08 \mathrm{db}$ which needed 11 hours, with the average drying chamber temperature, drying chamber relative humidity, and an air mass flow rate of $70.5^{\circ} \mathrm{C}, 10.1 \%$, and $0.124 \mathrm{~kg} / \mathrm{s}$, respectively, while the open sun drying needed $62 \mathrm{hours}$. Compared to open sun drying, this dryer yielded $82 \%$ saving in drying time. The drying rate, the specific moisture extraction rate, and thermal efficiency of the dryer were estimated in average to be about $1.57 \mathrm{~kg} / \mathrm{h}, 0.14 \mathrm{~kg} / \mathrm{kWh}$, and $9.03 \%$, respectively. Three mathematical models, the Newton, Henderson-Pabis, and Page models, were fitted to the experimental data on red chillies dried by solar assisted heat pump dryer integrated with biomass furnace and open sun drying. The performance of these models was evaluated by comparing the coefficient of determination $\left(R^{2}\right)$, mean bias error (MBE), and root mean-square error (RMSE). The Page model gave the best results for representing drying kinetics of red chillies.
\end{abstract}

\section{Introduction}

Indonesia is an agricultural country and produced 1,075,000 tons chilli in the year 2014, including red chilli [1]. Red chilli is an important ingredient in daily cuisine in Indonesia. It is consumed as fresh, dried, and powder forms. Red chilli is rich in protein, carbohydrates, calcium, phosphorus, vitamins A and $\mathrm{C}$. It can be used to prevent heart diseases by dilating blood vessels and antioxidant $[2,3]$.

Commonly, fresh red chillies are dried using open sun drying. It is very simple and has low investment and operating costs. However, the open sun drying has disadvantages such as depending on the weather conditions, low quality products, and slow drying rate or long drying times. Solar dryer is one of the alternatives to solve this problem.

Some researchers have developed and tested several types of solar dryer to reduce drying time and to maintain the quality of red chillies obtained by open sun drying. Fudholi et al. $[2,4]$ reported that by using an indirect forced convection solar dryer for drying red chilli with a drying capacity of $40 \mathrm{~kg}$ the dryer was able to reduce the moisture content of $80 \%$ (wet basis) to $10 \%$ (wet basis) during 10 hours, while the open sun drying needed 65 hours. Also, they reported that the dryer can save the drying time of approximately $49 \%$ compared to open sun drying. Kaewkiew et al. [5] found that by using a large-scale greenhouse type solar dryer for drying red chilli with a drying capacity of $500 \mathrm{~kg}$ this dryer only takes 3 days to reduce moisture content as much as $74 \%$ (wet basis) to $9 \%$ (wet basis), whereas open sun drying takes 5 days. Solar dryer was estimated which can save the drying time of about $40 \%$ compared to open sun drying. In addition, good quality of red chilli was obtained. Palled et al. [6] evaluated the performance of a solar tunnel dryer for drying red chilli. The result showed that the drying of $350 \mathrm{~kg}$ red chilli using this dryer needs 50 hours for reducing its moisture content from $76 \%$ (wet basis) to $9 \%$ (wet basis), while the open sun drying needs 105 hours. They found that the solar dryer saves $52.38 \%$ in the drying time compared to open sun drying. Banout et al. [7] reported the use of a double-pass solar dryer for drying red chilli. Drying $40 \mathrm{~kg}$ of red chilli using this dryer, the moisture content reduced from approximately $90 \%$ (wet basis) to $10 \%$ (wet basis) within 32 hours, while open sun drying took 93 hours. Also, they found that by using this dryer we can save the drying time about $65.59 \%$ compared to open sun drying. 
Good quality products were obtained. Furthermore, Janjai et al. [3] found that by using a large-scale solar greenhouse using polycarbonate cover dryer for drying chilli with a drying capacity of $300 \mathrm{~kg}$ the dryer requires drying time for 3 days to reduce the moisture content from 75\% (wet basis) to $15 \%$ (wet basis), while open sun drying takes 5 days. Also, solar dryer can save the drying time of approximately $40 \%$ over open sun drying. In addition, good quality dried product was obtained. Based on the results of the testing several researchers conclude that the solar dryers save over $39 \%$ of drying time of red chillies compared to open sun drying. However, the drying process can not be conducted or continued during the cloudy, rainy days and the night time because there is either no or low sunlight. Therefore, it is necessary to provide the solar dryers with an auxiliary heater, such as biomass furnace by using biomass as heat energy sources. Leon and Kumar [8] have evaluated the performance of a solar assisted biomass drying system with thermal storage for drying red chilli. They found that the drying of $22 \mathrm{~kg}$ red chilli using this dryer needs 32.5 hours of continuous drying for reducing its moisture content from $76.7 \%$ (wet basis) to $8.4 \%$ (wet basis), with the air drying temperature of $60^{\circ} \mathrm{C}$ and air flow rate of $90 \mathrm{~m}^{3} / \mathrm{h}$, while the open sun drying needs 4 days. They found that the solar dryer saves $66 \%$ in the drying time compared to open sun drying. The solar assisted biomass drying system with thermal storage is also known as hot dryer because to decrease the drying time is done by increasing the air temperature. The high drying temperature causes damage to the flavour, colour, and nutrients of the dried chillies [9]. To overcome this problem, the drying time can be shortened by decreasing the air humidity. It can be done by removing or dehumidifying of the water vapor in the air by using dehumidifier such as heat pump. Dezfouli et al. [10] have evaluated the performance of a solar assisted heat pump dryer for drying red chilli. The result showed that the drying of $15 \mathrm{~kg}$ red chilli using this dryer needs 32 hours for reducing its moisture content from 4 on dry basis to 0.08 on dry basis, with an average temperature of $46^{\circ} \mathrm{C}$, relative humidity of $27 \%$, and air mass flow rate of $0.15 \mathrm{~kg} / \mathrm{h}$, while the open sun drying needs 64 hours. They found that the solar dryer saves $50 \%$ in the drying time compared to open sun drying. However, the drying air temperature is low at cloudy, rainy days and the night time. This will lead to long drying time because it limited the heat pump operating temperature refrigerant and compressor operating conditions.

Solar assisted heat pump dryer integrated with biomass furnace can be used for drying red chillies to resolve the disadvantages of the current drying techniques. It has many advantages such as low relative humidity, and the drying processes can be conducted at cloudy, rainy days and the night time.

Indonesia is a tropical country and is located in the equator line. The country receives a daily average solar radiation about $4 \mathrm{kWh} / \mathrm{m}^{2}$ [11]. Also, Indonesia is one of the largest biomass producing countries in the world with its production of approximately 236 million tons of biomass per year, equivalent to about 756.083 mill GJ per year [12]. Therefore, the purpose of this paper is to design and to evaluate performance of a solar assisted heat pump dryer integrated with

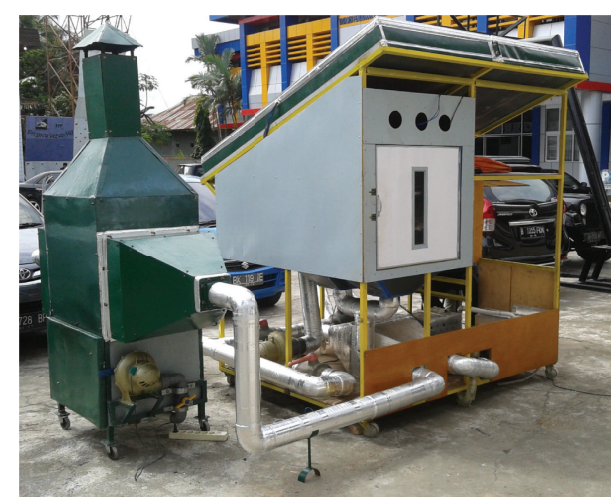

FIGURE 1: Photograph of the solar assisted heat pump drying integrated with biomass furnace.

biomass furnace for drying red chilli in Indonesia and to investigate the drying characteristics of red chilli in a solar assisted heat pump dryer integrated with biomass furnace and open sun drying and to fit the experimental data to select the best mathematical models.

\section{Material and Methods}

2.1. Experimental Set-Up. A solar assisted heat pump dryer integrated with biomass furnace was designed and installed at the Institute of Technology, Padang, West Sumatra, Indonesia. The drying system consists of solar collector array, heat pump, biomass furnace, drying chamber, and blower shown in Figures 1 and 2. The solar collector is equipped with transparent cover glass material, absorber plate finned used aluminum and black painted opaque, angle iron frame, inside and outside the collector coated with aluminum $1 \mathrm{~mm}$ thick, and insulation using glass fiber materials. Two solar collectors are connected in series with an area of $1.8 \mathrm{~m}^{2}$ each, shown in Figure 3. The heat pump consists of several main parts: evaporator, condenser, compressor, and expansion valve. The working fluid of the heat pump is R-22. Compressor use of electrical capacity is $0.746 \mathrm{~kW}$. The dimension of evaporator and condenser of the heat pump is shown in Figure 4. The biomass furnace consists of several main parts such as the combustion chamber, heat exchanger, chimney, and blower. The wall of the combustion chamber uses brick, cement, and steel plate materials and heat exchanger pipes using mild steel with diameter of $2 \mathrm{inch}$ and number of pipes is 16 units, dimension of biomass furnace shown in Figure 5. The drying chamber uses the cabinet type and contains the drying trays with adjustable racks to place the red chilli. Its walls consist of triple layers, an outside layer which uses aluminum sheet, a middle one insulated with glass fiber materials, and inner layer which uses of aluminum sheet, dimension of drying chamber shown in Figure 6. The drying air is circulated by using blower with electrical capacity of $0.75 \mathrm{~kW}$.

2.2. Experimental Procedure. The experiments were carried out at Padang Institute of Technology, West Sumatra, Indonesia. Fresh red chilli was purchased at the local market in 


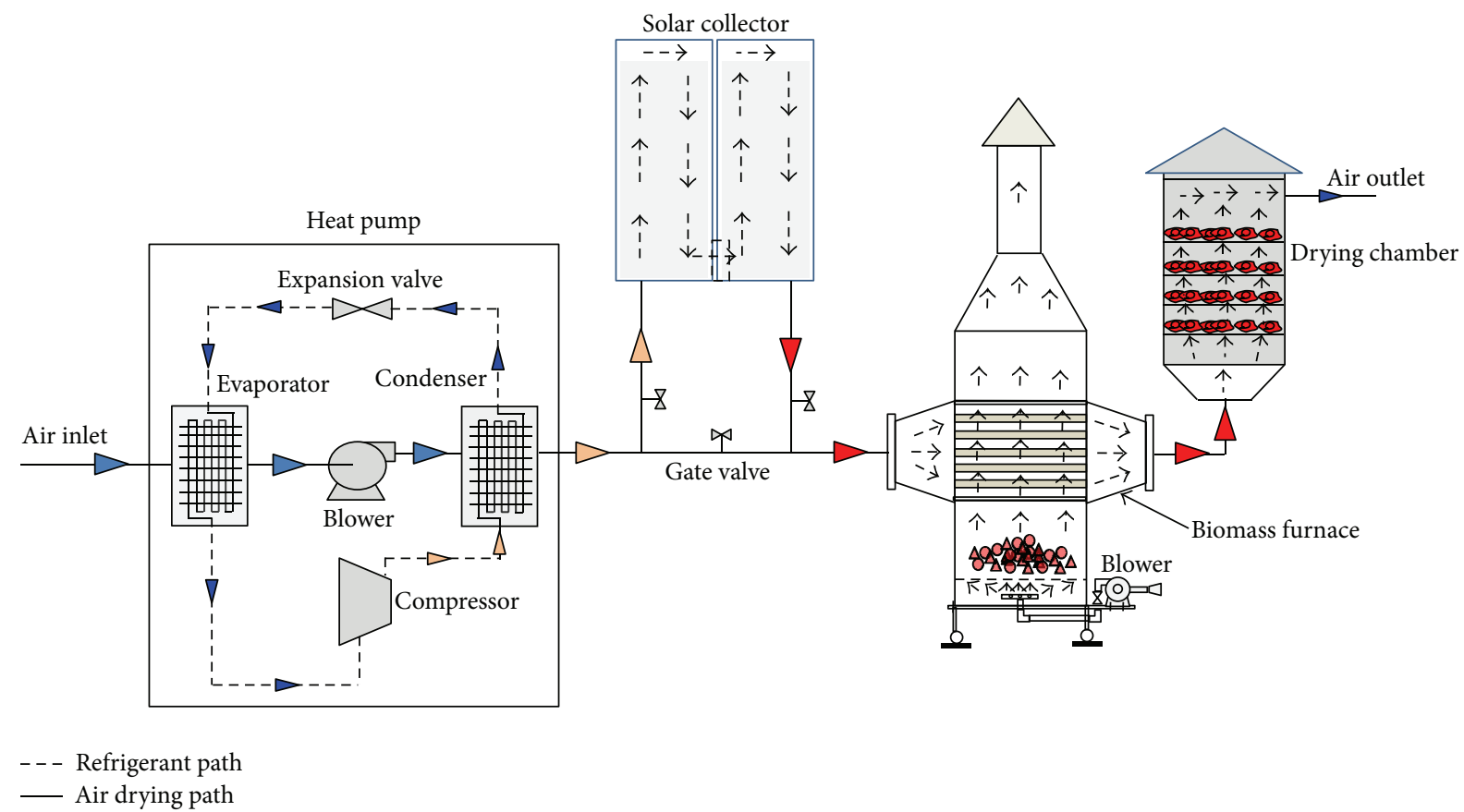

FIGURE 2: Schematic diagram of the solar assisted heat pump drying integrated with biomass furnace.
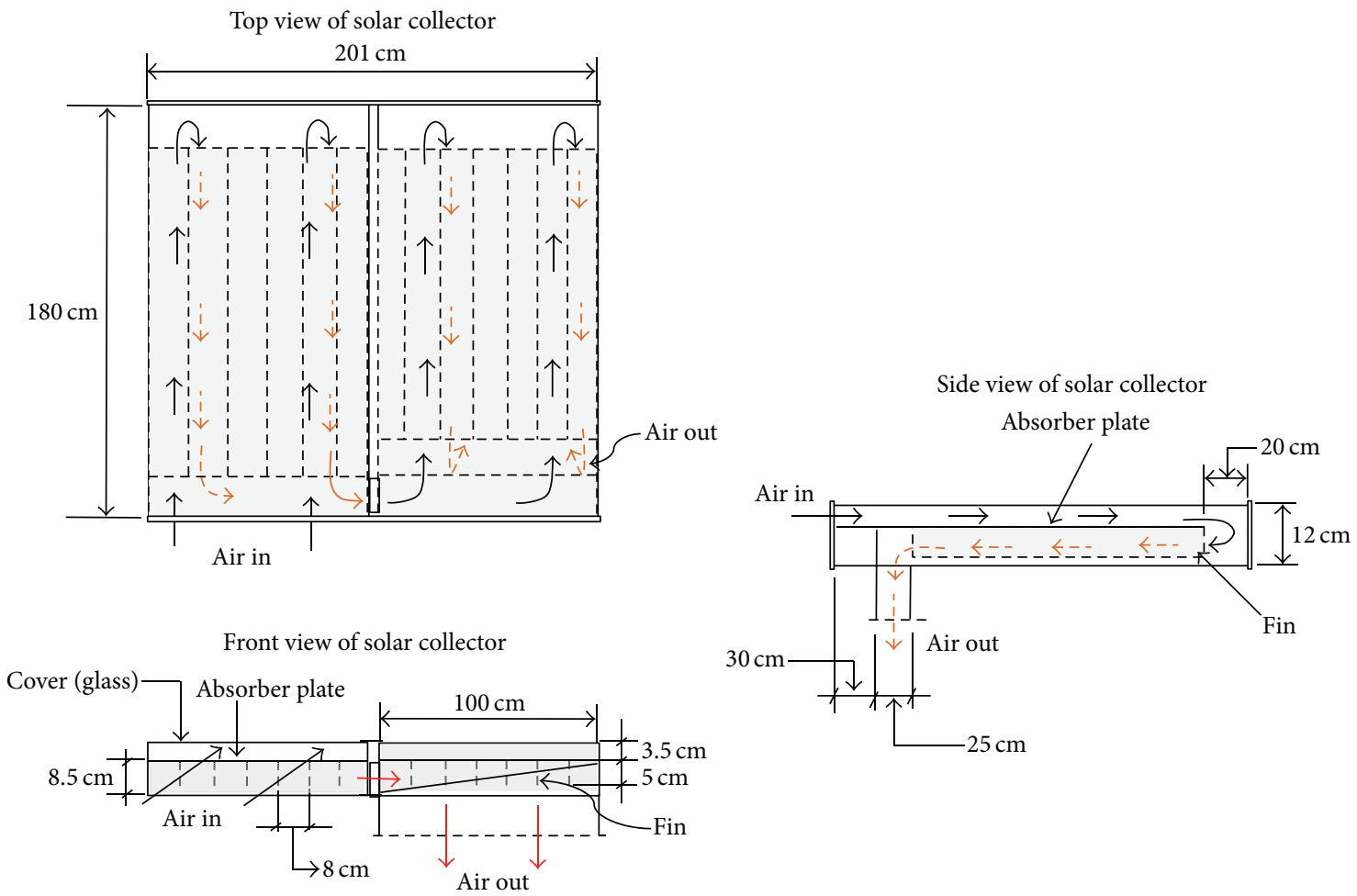

Figure 3: Dimensions of a double-pass solar collector with fin.

Padang. As much as $22 \mathrm{~kg}$ was placed into the drying chamber for the drying process shown in Figure 7.

Incoming and outgoing air temperature of solar collector, heat pump, biomass furnace, and drying chamber during the operation of the drying system were measured by using $\mathrm{T}$ type copper-constantan thermocouples with an accuracy of $\pm 0.1^{\circ} \mathrm{C}$ and operating temperature range $\left(-200^{\circ} \mathrm{C}\right.$ to $\left.400^{\circ} \mathrm{C}\right)$. The solar radiation was measured by an LI-200 pyranometer in $\pm 0.1 \mathrm{Wm}^{-2}$ accuracy and with maximum solar radiation of $2000 \mathrm{Wm}^{-2}$, operating temperature range $\left(-40^{\circ} \mathrm{C}\right.$ to $\left.400^{\circ} \mathrm{C}\right)$ 

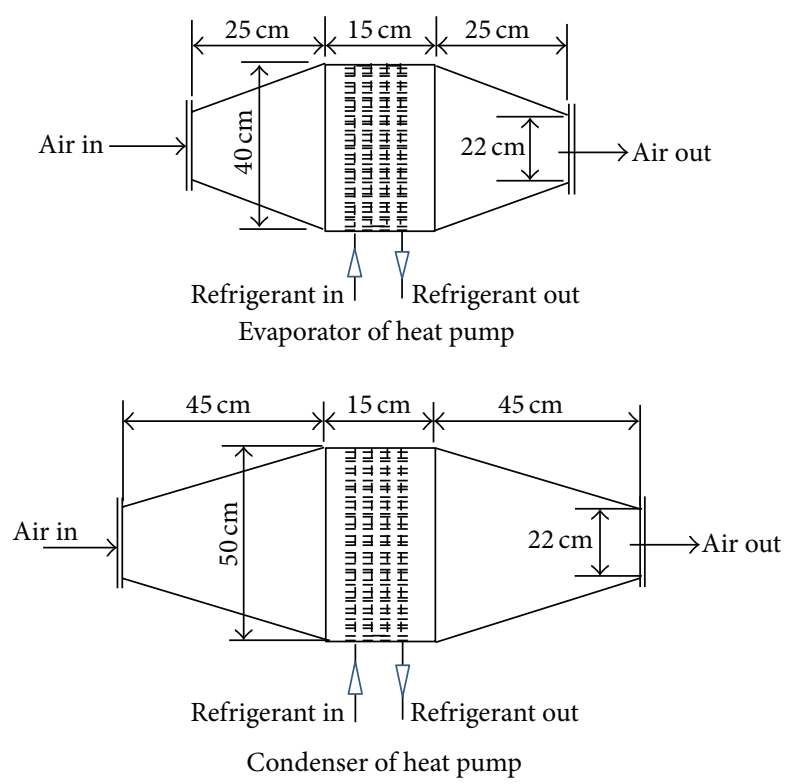

FIGURE 4: Dimensions of evaporator and condenser of heat pump.

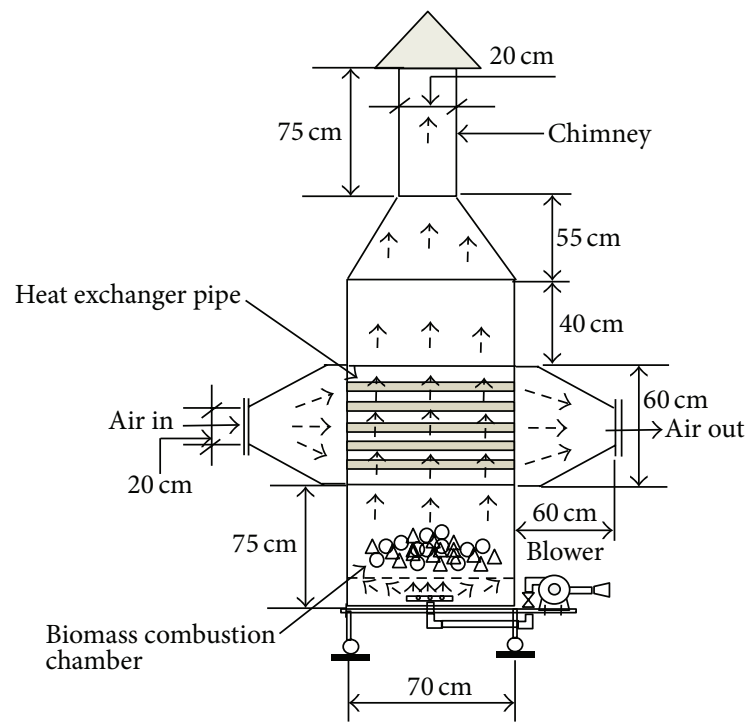

Figure 5: Dimensions of biomass furnace.

and operating relative humidity range ( $0 \%$ to $100 \%)$. The air velocity was measured with $0-30 \mathrm{~ms}^{-1}$ range, an HT383 anemometer, an accuracy of $\pm 0.2 \mathrm{~ms}^{-1}$, and operation temperature range $\left(-10^{\circ} \mathrm{C}\right.$ to $\left.45^{\circ} \mathrm{C}\right)$. The air temperature and the solar radiation were recorded by an $\mathrm{AH} 4000$ data logger with reading accuracy of $\pm 0.1^{\circ} \mathrm{C}$. The weight change of the red chilli was measured by $0-15 \mathrm{~kg}$ range, an TKB- 0.15 weighing scale, an accuracy $\pm 0.05 \mathrm{~kg}$. Red chillies were weighed every 60 minutes and temperature was measured every 30 minutes.

\subsection{Experimental Data Analysis}

2.3.1. Performance of Drying System. The performance of solar assisted heat pump dryer integrated with biomass furnace is characterized by drying rate, specific moisture extraction rate, and dryer thermal efficiency. It is highly depending on the performance of each of the drying system components such as solar collector, heat pump, and biomass furnace.

The thermal efficiency of a solar collector is the ratio of useful heat gain by solar collector to the energy incident in the plane of the collector. It is calculated as [13]

$$
\eta_{\text {coll }}=\frac{\dot{m}_{\text {air }} C_{P \text { air }}\left(T_{o, \text { coll }}-T_{i, \text { coll }}\right)}{I_{T} A_{C}} \times 100 \%
$$

where $\dot{m}_{\text {air }}$ is air mass flow rate, $C_{P \text { air }}$ is specific heat of air, and $T_{i, \text { coll }}$ and $T_{o \text {,coll }}$ are inlet and outlet air temperatures of solar collector, respectively. $A_{C}$ is an area of collector and $I_{T}$ is solar radiation incident in the collector.

The coefficient of performance of a heat pump is the ratio of useful heat or heat energy released by the refrigerant in the condenser to the electrical energy consumed by compressor. It is calculated as [14]

$$
\mathrm{COP}_{\mathrm{hp}}=\frac{\dot{m}_{\mathrm{air}} C_{P \text { air }}\left(T_{o, \text { cond }}-T_{i, \text { cond }}\right)}{E_{\text {comp }}}
$$

where $T_{i, \text { cond }}$ and $T_{o \text {,cond }}$ are inlet and outlet air temperatures of condenser, respectively, and $E_{\text {comp }}$ is the electrical energy consumed by the compressor.

The electrical energy consumed by compressor was calculated using the following equation [15]:

$$
E_{\text {comp }}=V I \cos \varphi \text {, }
$$

where $V$ is the line voltage, $I$ is the line current, and $\cos \varphi$ is the power factor.

The thermal efficiency of a biomass furnace is the ratio of useful heat by biomass furnace to the heat energy generated by the combustion of the biomass fuel. It is calculated as [16]

$$
\eta_{\mathrm{bf}}=\frac{\dot{m}_{\mathrm{air}} C_{P \mathrm{air}}\left(T_{o, \mathrm{bf}}-T_{i, \mathrm{bf}}\right)}{\dot{m}_{\mathrm{bmf}} \mathrm{CV}_{\mathrm{bmf}}} \times 100 \%,
$$

where $T_{i, b f}$ and $T_{o, b f}$ are the inlet and outlet air temperatures of biomass furnace, respectively, $\dot{m}_{\mathrm{bmf}}$ is biomass fuel consumption rate, and $\mathrm{CV}_{\mathrm{bmf}}$ is caloric value of biomass fuel. The biomass fuel uses coconut shell charcoal with a caloric value of about $7600 \mathrm{kcal} / \mathrm{kg}$ [17].

The moisture content of the red chillies can be estimated by two methods such as wet and dry basis using the following equation [10].

The moisture content wet basis was calculated as

$$
\mathrm{MC}_{\mathrm{wb}}=\frac{m_{w}}{m_{w}+m_{d}} .
$$

The moisture content dry basis was calculated as

$$
\mathrm{MC}_{\mathrm{db}}=\frac{m_{\mathrm{wetrc}}-m_{d}}{\dot{m}_{d}},
$$

where $m_{w}$ is the mass of water of the red chillies, $m_{d}$ is the mass of bone dry of the red chillies, and $m_{\text {wetrc }}$ is mass of wet red chillies. 


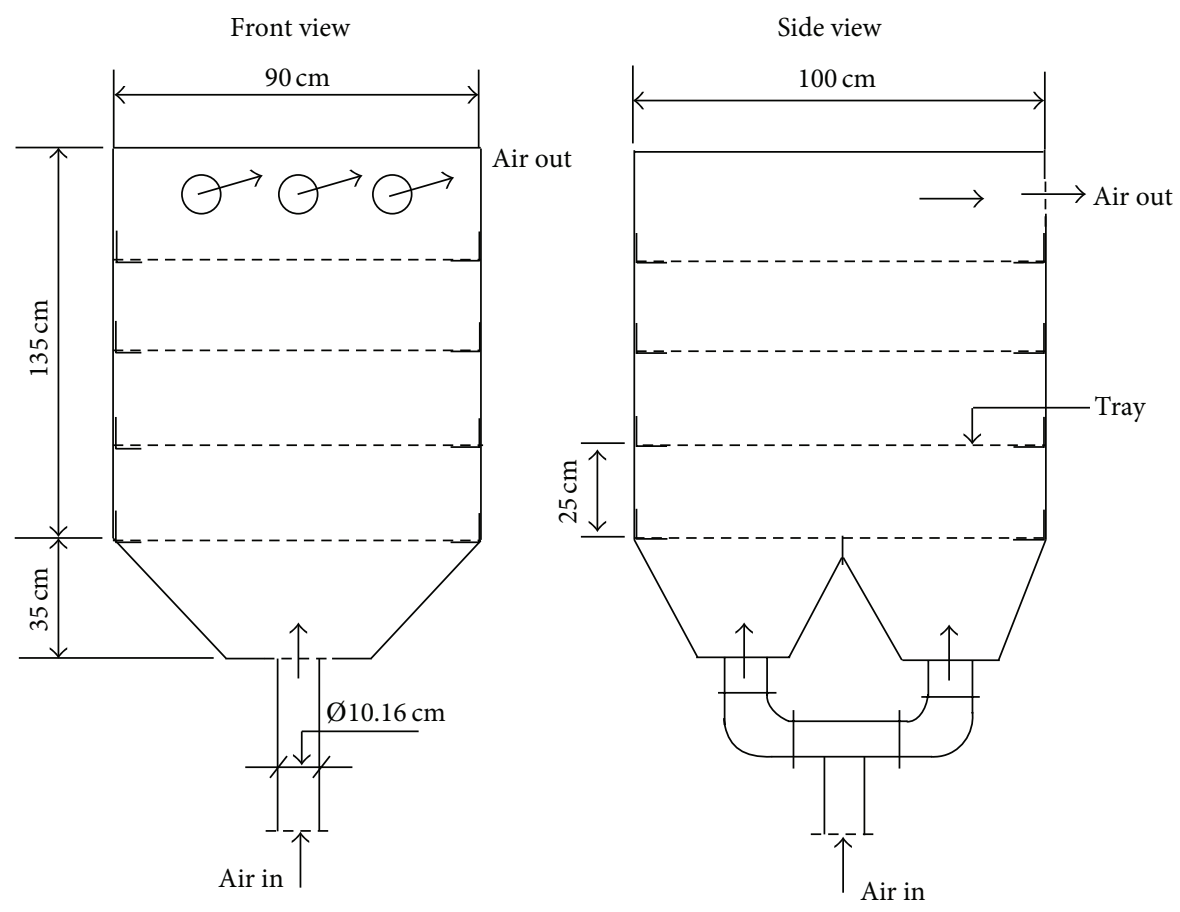

FIGURE 6: Dimensions of drying chamber.

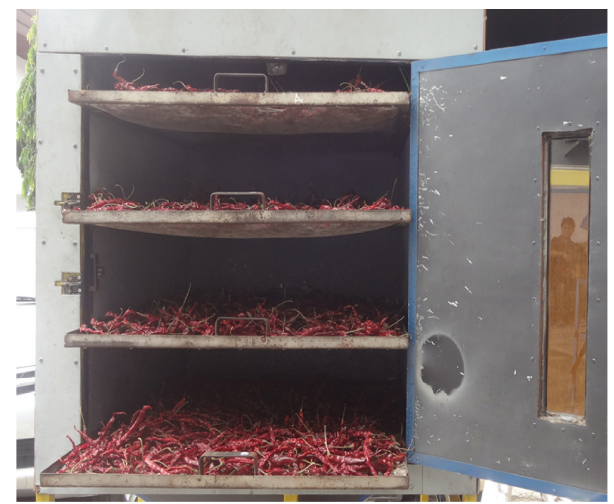

FIGURE 7: Photograph of red chilli in drying chamber.

The drying rate is the mass of water evaporated from the wet red chillies per unit time. It is calculated using the following equation [2]:

$$
\mathrm{DR}=\dot{m}_{\mathrm{water}}=\frac{m_{\mathrm{water}}}{t}
$$

where $m_{\text {water }}$ is the mass of water evaporated and $t$ is drying time.

The mass of the water evaporated ( $\left.m_{\text {water }}\right)$ from the wet red chillies can be calculated as [18]

$$
m_{\text {water }}=\frac{m_{\text {wetrc }}\left(M_{i}-M_{f}\right)}{\left(100-M_{f}\right)} \text {, }
$$

where $m_{\text {wetrc }}$ is initial mass of wet red chillies, $M_{i}$ is initial moisture content on wet basis, and $M_{f}$ is final moisture content on the wet basis.

The specific moisture extraction rate (SMER) is the ratio of the moisture evaporated from wet red chillies to the energy input to drying system. It is calculated as [19]

$$
\mathrm{SMER}=\frac{\dot{m}_{\mathrm{water}}}{E_{\mathrm{s}}+E_{\mathrm{bmf}}+E_{\mathrm{comp}}+E_{\mathrm{bl}}},
$$

where $E_{s}$ is energy incident in the plane of the solar collector and $E_{\mathrm{bmf}}$ is heat energy generated by the combustion of biomass fuel. $E_{\text {comp }}$ and $E_{\mathrm{bl}}$ are electrical energy consumed by compressor and blower, respectively.

The thermal efficiency of dryer is the ratio of the energy used for moisture evaporation to the energy input to drying system. It is calculated as [20]

$$
\eta_{\text {dryer }}=\frac{\dot{m}_{\text {water }} H_{\mathrm{fg}}}{E_{s}+E_{\mathrm{bmf}}+E_{\mathrm{comp}}+E_{\mathrm{bl}}},
$$

where $H_{\text {fg }}$ is the latent heat of vaporization of water.

The heat energy used by the drying system for drying red chillies is a contribution from the drying system components such as solar collector, condenser, and biomass furnace. The percentage of heat energy contribution by the solar collector, condenser, and biomass furnace is calculated using (11), (12), and (13), respectively [8].

The percentage of heat energy contribution by solar collector can be calculated as follows:

$$
\mathrm{HEC}_{\text {coll }}=\frac{Q_{\text {Ucoll }}}{Q_{\text {Ucoll }}+Q_{\text {Ucond }}+Q_{\text {Ubf }}} .
$$


TABLE 1: Mathematical models used for drying curves.

\begin{tabular}{lcc}
\hline Model name & \multicolumn{1}{c}{ Model } & References \\
\hline Newton & $\mathrm{MR}=\exp (-\mathrm{kt})$ & {$[23,24]$} \\
Henderson and Pabis & $\mathrm{MR}=a \exp (-\mathrm{kt})$ & {$[25,26]$} \\
Page & $\mathrm{MR}=\exp \left(-\mathrm{kt}^{n}\right)$ & {$[27,28]$} \\
\hline
\end{tabular}

The percentage of heat energy contribution by condenser can be calculated as follows:

$$
\mathrm{HEC}_{\text {cond }}=\frac{Q_{\mathrm{Ucond}}}{Q_{\mathrm{Ucond}}+Q_{\mathrm{Ucoll}}+Q_{\mathrm{Ubf}}} .
$$

The percentage of heat energy contribution by biomass furnace can be calculated as follows:

$$
\mathrm{HEC}_{\mathrm{bf}}=\frac{Q_{\mathrm{Ubf}}}{Q_{\mathrm{Ubf}}+Q_{\mathrm{Ucoll}}+Q_{\mathrm{Ucond}}},
$$

where $Q_{U c o l l}$ is the useful heat gain by solar collector, $Q_{U \text { cond }}$ is the useful heat or heat energy released by refrigerant in the condenser, and $Q_{\mathrm{Ubf}}$ is the useful heat by biomass furnace.

2.3.2. Mathematical Modelling of Drying Curves. The experimental drying data obtained were fitted to the three best drying models given in Table 1 . The dimensionless moisture content was calculated as follows [21]:

$$
\mathrm{MR}=\frac{\left(M_{t}-M_{e}\right)}{\left(M_{o}-M_{e}\right)},
$$

where $\mathrm{MR}$ is the dimensionless moisture content and $M_{e}$, $M_{o}$, and $M_{t}$ are the equilibrium moisture content, the initial moisture content, and the moisture content at any time on dry basis, respectively.

The regression analysis was performed using Statistica computer program. The correlation coefficient $\left(R^{2}\right)$ was primary criterion for selecting the best equation to describe the drying curve equation. The values of the coefficient of determination $\left(R^{2}\right)$, mean bias error $(\mathrm{MBE})$, and root mean-square error (RMSE) were used to analyze the relative goodness of the fit. These parameters can be calculated as follows [22]:

$$
\begin{aligned}
\mathrm{MBE} & =\frac{1}{N} \sum_{i=1}^{N}\left(\mathrm{MR}_{\mathrm{pre}, i}-\mathrm{MR}_{\text {exp }, i}\right)^{2}, \\
\mathrm{RMSE} & =\left[\frac{1}{N} \sum_{i=1}^{N}\left(\mathrm{MR}_{\mathrm{pre}, i}-\mathrm{MR}_{\text {exp }, i}\right)^{2}\right]^{1 / 2},
\end{aligned}
$$

where $\mathrm{MR}_{\exp , i}$ is the $i$ th experimental dimensionless moisture content, $\mathrm{MR}_{\mathrm{pre}, i}$ is the $i$ th predicted dimensionless moisture content, $N$ is the number of observations, and $n$ is the number constants.

2.4. Experimental Uncertainty. In the drying experiments of the red chillies the data was obtained by appropriate instrument; however, errors and uncertainties can arise because

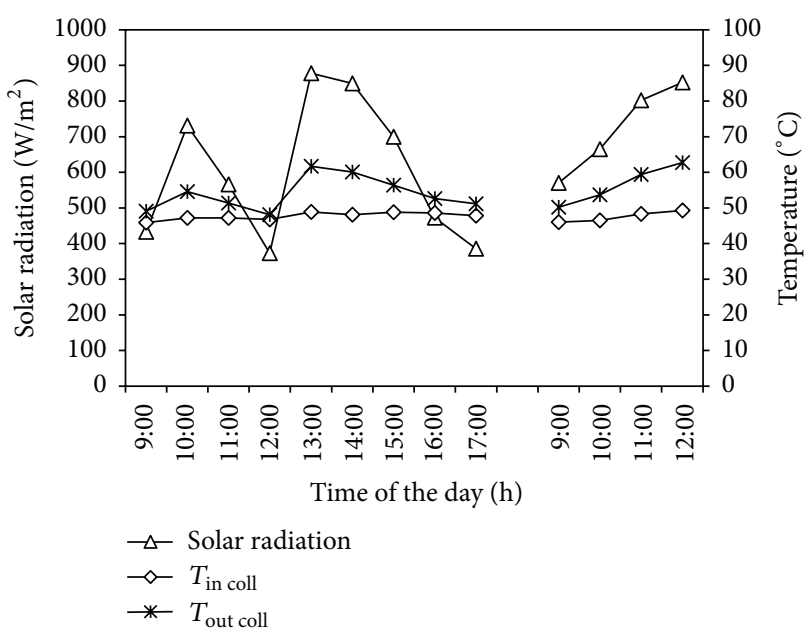

FIGURE 8: The variation of solar radiation and temperature with time of the day.

of the situations such as instrument selection, condition, environment, observation, reading, and test planning. Uncertainty was calculated using the following equation $[29,30]$ :

$$
\begin{aligned}
& W_{R} \\
& =\left[\left(\frac{\partial R}{\partial x_{1}} w_{1}\right)^{2}+\left(\frac{\partial R}{\partial x_{2}} w_{2}\right)^{2}+\cdots+\left(\frac{\partial R}{\partial x_{n}} w_{n}\right)^{2}\right]^{1 / 2} .
\end{aligned}
$$

\section{Results and Discussion}

The variations of solar radiation and inlet and outlet air temperatures of the solar collector with time of the day are shown in Figure 8. As seen from the figure the weather is quite bright with an average solar radiation of $637 \mathrm{Wm}^{-2}$ which was observed. The inlet air temperature of the solar collector is varied between $45.9^{\circ} \mathrm{C}$ and $49.3^{\circ} \mathrm{C}$ and in average is $47.6^{\circ} \mathrm{C}$. Meanwhile, the outlet air temperature of the solar collector is varied between $49.1^{\circ} \mathrm{C}$ and $62.7^{\circ} \mathrm{C}$ and in average is $54.7^{\circ} \mathrm{C}$. Also it is observed from the figure that the outlet air temperature of the solar collector is very dependent on the solar radiation; when solar radiation is high, the outlet air temperature of the solar collector is also high, and vice versa. The evaluation of the uncertainty of dryer performance is presented in Table 2 .

The variations of solar radiation and efficiency of solar collector with time of the day are shown in Figure 9. The maximum, minimum, and average of the solar collector efficiency were estimated to be about $12.0 \%, 54.6 \%$, and $35.1 \%$, respectively, with an air mass flow rate being about $0.1254 \mathrm{kgs}^{-1}$. As observed from the figure the solar collector is very sensitive to solar radiation; if the solar radiation fluctuates, the solar collector efficiency also fluctuates.

The variations of air temperatures and relative humidities inlet and outlet of the heat pump are shown in Figure 10. The inlet and outlet air temperature of the heat pump are varied between $31.2^{\circ} \mathrm{C}$ and $37.2^{\circ} \mathrm{C}$ and $47.5^{\circ} \mathrm{C}$ and $50.3^{\circ} \mathrm{C}$ and in average are about $34.1^{\circ} \mathrm{C}$ and $49.1^{\circ} \mathrm{C}$, respectively. Meanwhile, 
TABLE 2: Uncertainties of the parameters during drying experiment of red chilli.

\begin{tabular}{|c|c|c|}
\hline Parameters & Unit & Uncertainty comment \\
\hline \multicolumn{3}{|l|}{ Measured } \\
\hline Ambient air temperature & ${ }^{\circ} \mathrm{C}$ & \pm 0.17 \\
\hline Inlet air temperature of heat pump & ${ }^{\circ} \mathrm{C}$ & \pm 0.17 \\
\hline Outlet air temperature of heat pump & ${ }^{\circ} \mathrm{C}$ & \pm 0.17 \\
\hline Inlet air temperature of condenser & ${ }^{\circ} \mathrm{C}$ & \pm 0.17 \\
\hline Outlet air temperature of condenser & ${ }^{\circ} \mathrm{C}$ & \pm 0.17 \\
\hline Inlet air temperature of solar collector & ${ }^{\circ} \mathrm{C}$ & \pm 0.17 \\
\hline Outlet air temperature of solar collector & ${ }^{\circ} \mathrm{C}$ & \pm 0.17 \\
\hline Inlet air temperature of biomass furnace & ${ }^{\circ} \mathrm{C}$ & \pm 0.17 \\
\hline Outlet air temperature of biomass furnace & ${ }^{\circ} \mathrm{C}$ & \pm 0.17 \\
\hline Inlet air temperature of drying chamber & ${ }^{\circ} \mathrm{C}$ & \pm 0.17 \\
\hline Outlet air temperature of drying chamber & ${ }^{\circ} \mathrm{C}$ & \pm 0.17 \\
\hline Ambient air relative humidity & $\%$ & \pm 0.22 \\
\hline Inlet air relative humidity of heat pump & $\%$ & \pm 0.22 \\
\hline Outlet air relative humidity of heat pump & $\%$ & \pm 0.22 \\
\hline Inlet air relative humidity of drying chamber & $\%$ & \pm 0.22 \\
\hline Outlet air relative humidity of drying chamber & $\%$ & \pm 0.22 \\
\hline Solar radiation & $\mathrm{W} / \mathrm{m}^{2}$ & \pm 0.14 \\
\hline Air velocity & $\mathrm{m} / \mathrm{s}$ & \pm 0.24 \\
\hline Mass loss of samples & $\mathrm{g}$ & \pm 0.014 \\
\hline Mass loss of products & $\mathrm{kg}$ & \pm 0.11 \\
\hline Reading values of table $\left(\rho, C_{p}, \mathrm{CV}\right.$, and $\left.H_{\mathrm{fg}}\right)$ & - & $\pm 0.1-0.2$ \\
\hline Time measurement & $\min$ & \pm 0.1 \\
\hline \multicolumn{3}{|l|}{ Calculated } \\
\hline Air mass flow rate & $\mathrm{kg} / \mathrm{s}$ & \pm 0.26 \\
\hline Power consumption of compressor & $\mathrm{kW}$ & \pm 0.056 \\
\hline Power consumption of blower & $\mathrm{kW}$ & \pm 0.037 \\
\hline Thermal efficiency of solar collector & $\%$ & \pm 0.39 \\
\hline Coefficient of performance of heat pump & - & \pm 0.37 \\
\hline Thermal efficiency of biomass furnace & $\%$ & \pm 0.458 \\
\hline Moisture content & g water/g wet material & \pm 0.024 \\
\hline Drying rate & $\mathrm{kg} / \mathrm{h}$ & \pm 0.18 \\
\hline Specific moisture extraction rate & $\mathrm{kg} / \mathrm{kWh}$ & \pm 0.336 \\
\hline Thermal efficiency of dryer & $\%$ & \pm 0.350 \\
\hline Contribution heat energy by condenser & $\%$ & \pm 0.736 \\
\hline Contribution heat energy by solar collector & $\%$ & \pm 0.736 \\
\hline Contribution heat energy by biomass furnace & $\%$ & \pm 0.736 \\
\hline
\end{tabular}

inlet and outlet air relative humidity of heat pump are varied between $50.3 \%$ and $62.7 \%$ and $26.2 \%$ and $32.7 \%$ and in average are about $57.4 \%$ and $28.8 \%$, respectively. The heat pump can increase the air temperature and can decrease the relative humidity with an average of about $15.0^{\circ} \mathrm{C}$ and $28.8 \%$, respectively.

The variations of inlet and outlet air temperatures and COP of the heat pump are shown in Figure 11. The average inlet and outlet temperatures of the condenser of about $26.9^{\circ} \mathrm{C}$ and $49.1^{\circ} \mathrm{C}$ were recorded. Meanwhile, the minimum, maximum, and average of the COP of the heat pump were estimated to be about $3.76,3.95$, and 3.84 , respectively, with an air mass flow rate being about $0.124 \mathrm{kgs}^{-1}$.
The variations of inlet and outlet air temperatures and efficiency of the biomass furnace are shown in Figure 12. The inlet and outlet air temperatures of the biomass furnace varied between $47.6^{\circ} \mathrm{C}$ and $61.2^{\circ} \mathrm{C}$ and $70.5^{\circ} \mathrm{C}$ and $75.3^{\circ} \mathrm{C}$ with an average of about $53.2^{\circ} \mathrm{C}$ and $72.8^{\circ} \mathrm{C}$, respectively. The minimum, maximum, and average of the efficiency of biomass furnace were estimated to be about $15 \%, 43.5 \%$, and $30.7 \%$, respectively, with an air mass flow rate of about $0.124 \mathrm{kgs}^{-1}$. As seen from the figure the biomass furnace efficiency achieved is quite low, because of a lot of heat loss to the environment.

The variations of air temperature and ambient, inlet, and outlet relative humidity of the drying chamber with drying 


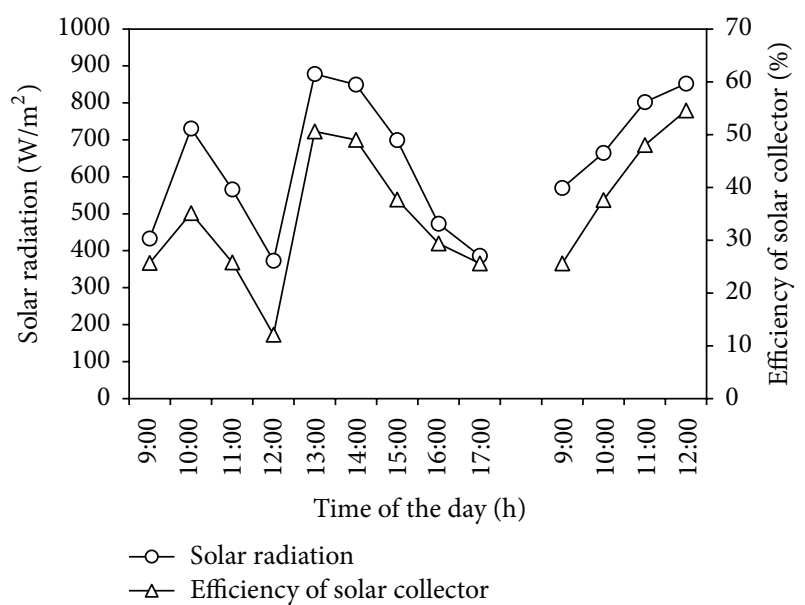

Figure 9: The variations of solar radiation and efficiency of solar collector with time of the day.

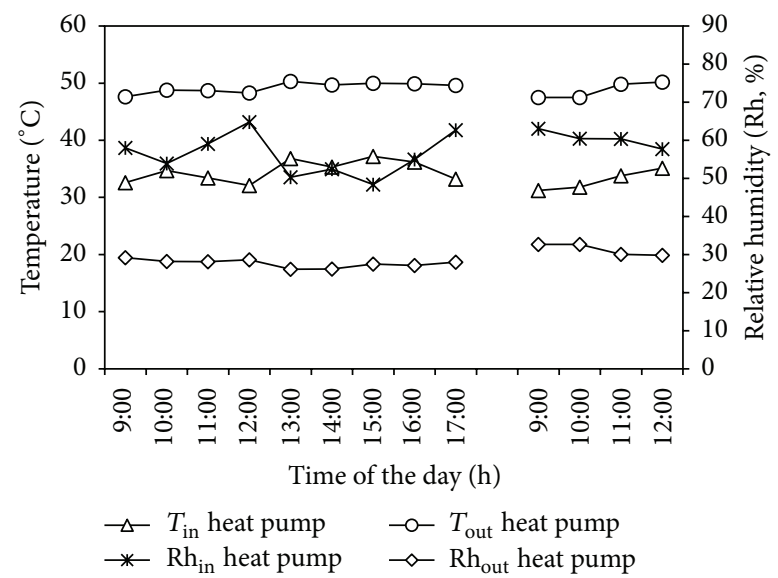

FIGURE 10: The variation of temperature and relative humidity with time of the day.

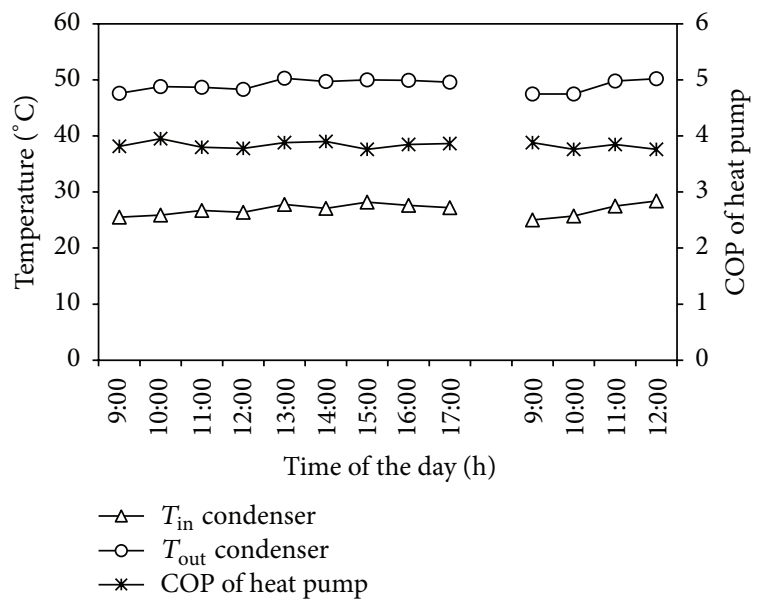

FIGURE 11: The variation of temperature and COP of the heat pump with time of the day.

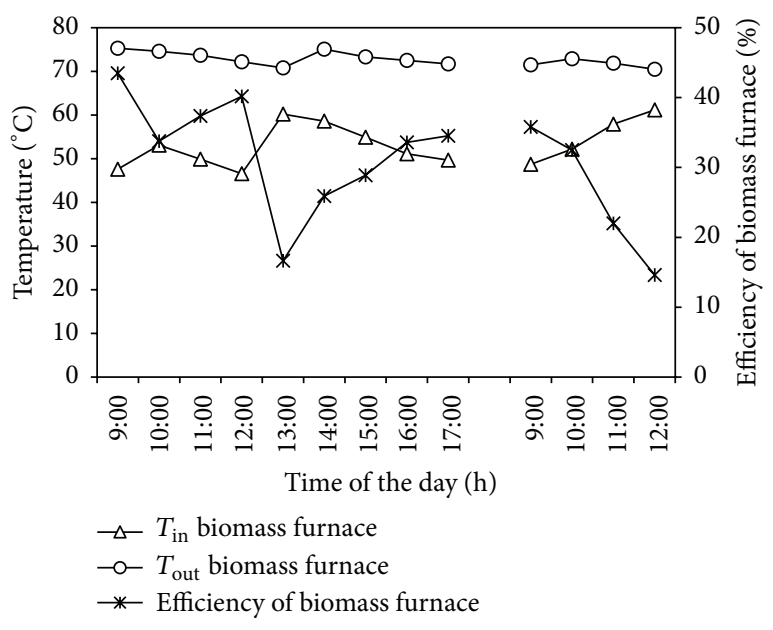

FIGURE 12: The variation of temperature and efficiency of the biomass furnace with time of the day.

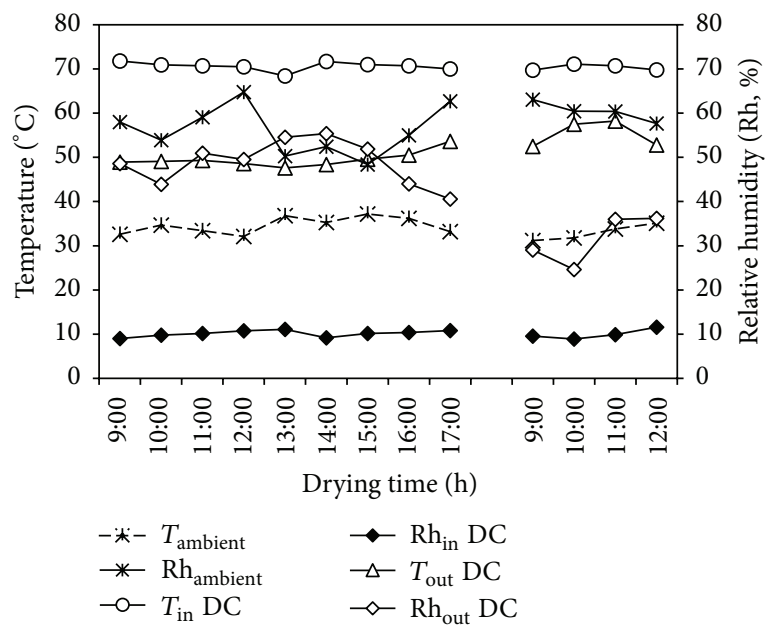

FIGURE 13: The variation of temperature and relative humidity with drying time.

time are shown in Figure 13. The drying chamber inlet temperature, drying chamber outlet temperature, drying chamber inlet relative humidity, and drying chamber outlet relative humidity are varied between $68.4^{\circ} \mathrm{C}$ and $71.8^{\circ} \mathrm{C}, 47.6^{\circ} \mathrm{C}$ and $58.2^{\circ} \mathrm{C}, 9.0 \%$ and $11.6 \%$, and $24.6 \%$ and $55.4 \%$, respectively, with corresponding average values of $70.5^{\circ} \mathrm{C}, 51.3^{\circ} \mathrm{C}, 10.1 \%$, and $43.5 \%$. The temperature ambient and relative humidity ambient are varied between $31.2^{\circ} \mathrm{C}$ and $33.8^{\circ} \mathrm{C}$ and $48.4 \%$ and $63.1 \%$, respectively, with corresponding average values of $34.1^{\circ} \mathrm{C}$ and $57.4 \%$. The results indicated that the air drying temperatures in solar assisted heat pump integrated with biomass furnace were higher than the ambient temperature; meanwhile the relative humidity in this dryer was lower than the ambient relative humidity. The difference values of air temperature and relative humidity were estimated to be about $36.4^{\circ} \mathrm{C}$ and $47.3 \%$, respectively, in the 11 -hour drying period. It can be stated that the drying rate in the dryer is higher than in open sun drying. As seen from figure the drying chamber outlet air temperature increased and the drying chamber 


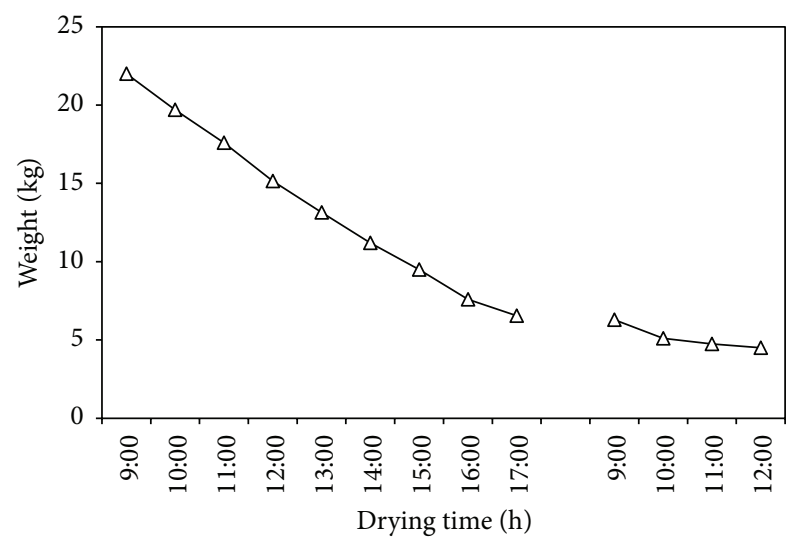

FIGURE 14: The variation of weight change of red chillies with drying time.

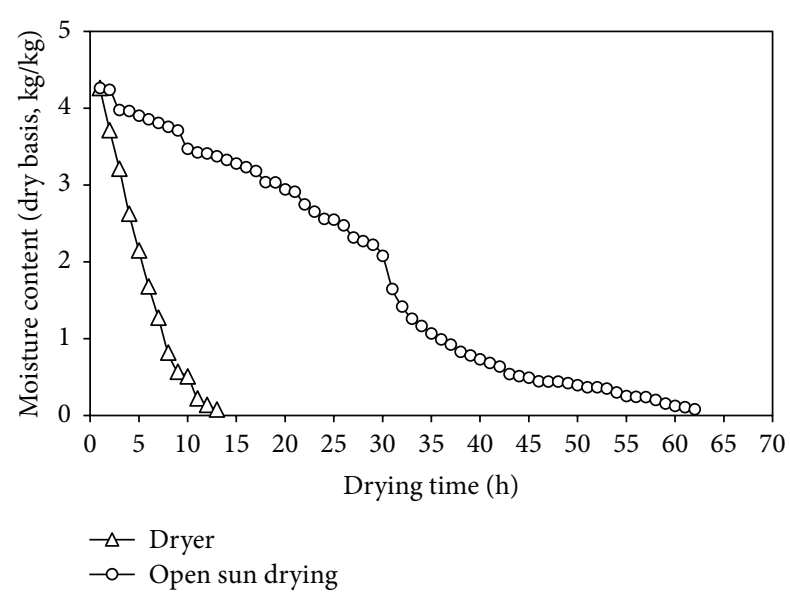

FIGURE 15: The variation of moisture content of dried red chilli in the solar assisted heat pump integrated with biomass furnace and open sun drying with drying time.

outlet relative humidity decreased with increasing in drying time. Due to these, the heat and mass transfer coefficients decreased in the drying time. Also it is observed from the figure that the air temperature of the outlet of the drying chamber is high, whereas the air relative humidity of the outlet of the drying chamber is low, and it is potential for recirculating to dry the red chilli.

The variation of weight change of red chillies with drying time is shown in Figure 14. As observed from the figure the weight of red chillies was reduced continuously with increasing in drying time. The weight of red chillies was reduced from $22 \mathrm{~kg}$ to $4.5 \mathrm{~kg}$ in 11 hours, with an air mass flow rate of $0.124 \mathrm{kgs}^{-1}$ and an averages drying air temperature and relative humidity of about $70.5^{\circ} \mathrm{C}$ and $10.1 \%$, respectively.

The variations of moisture content of dried red chilli in the solar assisted heat pump integrated with biomass furnace and open sun drying with drying time are shown in Figure 15. The moisture content was dried of red chilli to final moisture content of about 0.08 on dry basis from 4.26 on dry basis. The time to reach the final moisture content for solar assisted heat pump integrated with biomass furnace

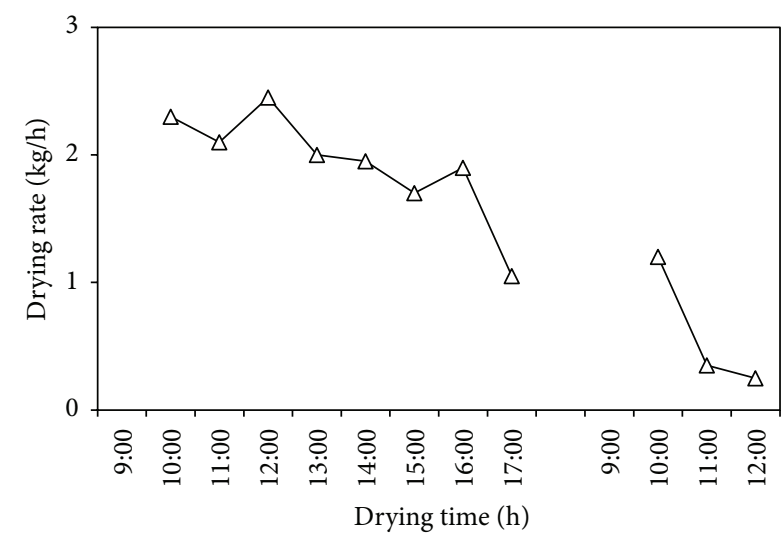

FIGURE 16: The variation of drying rate with drying time.

was found to be about 11 hours, with an air mass flow rate of $0.124 \mathrm{kgs}^{-1}$ and an average drying air temperature and relative humidity of about $70.5^{\circ} \mathrm{C}$ and $10.1 \%$, respectively. Meanwhile, the drying time of open sun drying was found to be about 62 hours, with an average ambient air temperature and ambient relative humidity of about $34.1^{\circ} \mathrm{C}$ and $57.4 \%$, respectively. The solar assisted heat pump integrated with biomass furnace had a shorter drying time compared to open sun drying. In other words, the dryer reduced the drying time or saved the drying time of about $82 \%$ compared to open sun drying. The decrease in drying time could be due to the values of higher temperature and lower relative humidity obtained in the dryer. At higher temperature and lower relative humidity, the difference in the partial vapor pressure between red chilli and the drying air is higher than at lower temperature and higher relative humidity. Hence, the moisture content transfer rate was more with higher air drying temperature.

The variation of drying rate with drying time is shown in Figure 16. The minimum, maximum, and average of the drying rate were estimated to be about $0.25 \mathrm{~kg} / \mathrm{h}, 2.45 \mathrm{~kg} / \mathrm{h}$, and $1.57 \mathrm{~kg} / \mathrm{h}$, respectively. As observed from the figure the drying rate decreased with increase in drying time. Due to this, the evaporation rate of moisture decreased in the drying time.

The variations of SMER and dryer thermal efficiency with drying time are shown in Figures 17 and 18. Figure 17 shows the variation of SMER with drying time. The minimum, maximum, and average of the SMER were estimated to be about $0.02,0.24 \mathrm{~kg} / \mathrm{kWh}$, and $0.14 \mathrm{~kg} / \mathrm{kWh}$, respectively. Figure 18 shows the variation of dryer thermal efficiency with drying time. The thermal efficiency varies from $1.34 \%$ to 15.36 with an average of $9.03 \%$, respectively. As observed from Figures 18 and 19 the SMER and the dryer thermal efficiency also decreased with increase in drying time. Due to these, the evaporation rate of moisture decreased in the drying time.

The variations of the contribution of heat energy with drying time are shown in Figure 19. The contribution of heat energy by the collector varies from about $2.7 \%$ to $30.0 \%$ and with average of $14.74 \%$, respectively. The contribution of heat energy by the condenser varies from about $43.7 \%$ to $50.4 \%$ and with average of $47.39 \%$, respectively. Meanwhile, 


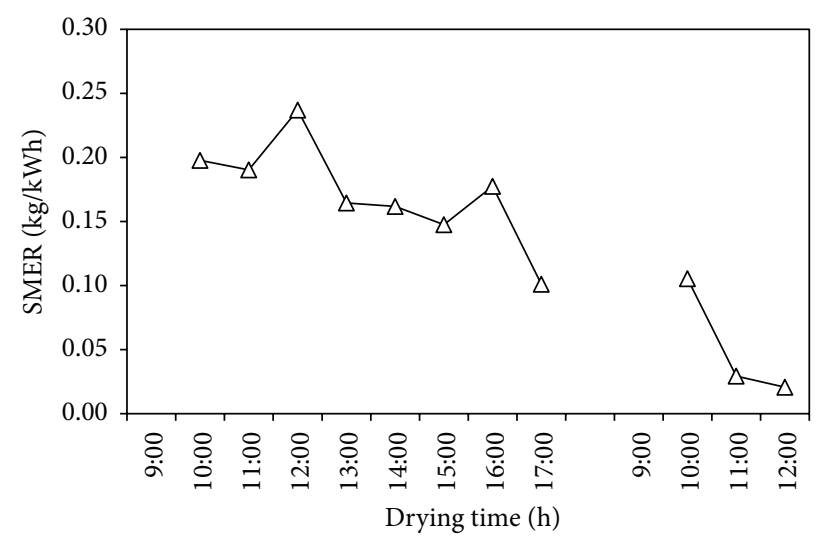

FIGURE 17: The variation of SMER with drying time.

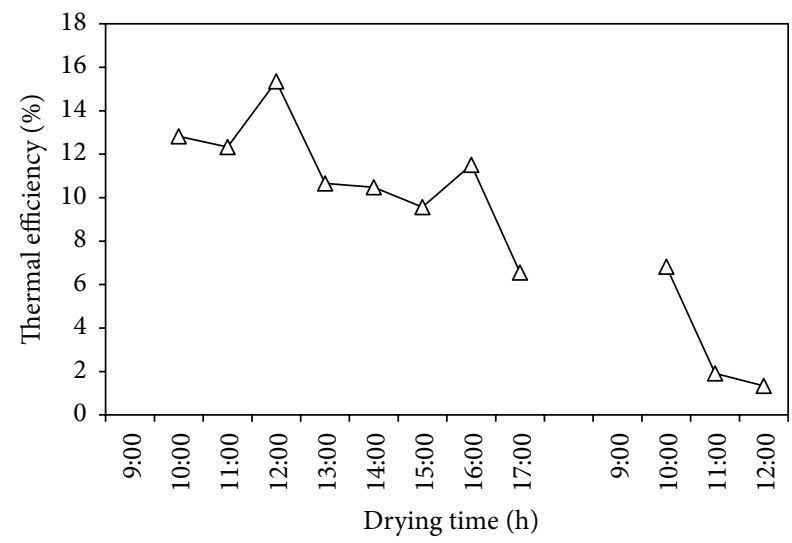

FIGURE 18: The variation of dryer thermal efficiency with drying time.

the contribution of heat energy by the biomass furnace varies from about $19.6 \%$ to $50.3 \%$ and with average of $37.87 \%$, respectively. Also it is observed from the figure that the contribution of heat energy by the condenser of heat pump is greater than the solar collector and biomass furnace, because the condenser can improve the drying air temperature reached with average value of $49.1^{\circ} \mathrm{C}$.

The experimental results of drying of red chilli using a solar assisted heat pump integrated with biomass furnace were compared with open sun drying and several types of solar dryers in references are shown in Table 3. In this dryer, the red chillies were dried from moisture content of 4.26 on dry basis to moisture content of 0.08 on dry basis which needed drying time 11 hours, with the average drying chamber temperature, drying chamber relative humidity, and an air mass flow rate of $70.5^{\circ} \mathrm{C}, 10.1 \%$, and $0.124 \mathrm{~kg} / \mathrm{s}$, respectively. Meanwhile, the drying time in several types of solar dryers in the references was varied from 32 hours to 50 hours. The results revealed that this dryer is better than several types of solar dryers in the references. This is because the drying time is lower than the several types of solar dryers in the references.

The variations of dimensionless moisture content data of dried red chilli in a solar assisted heat pump integrated

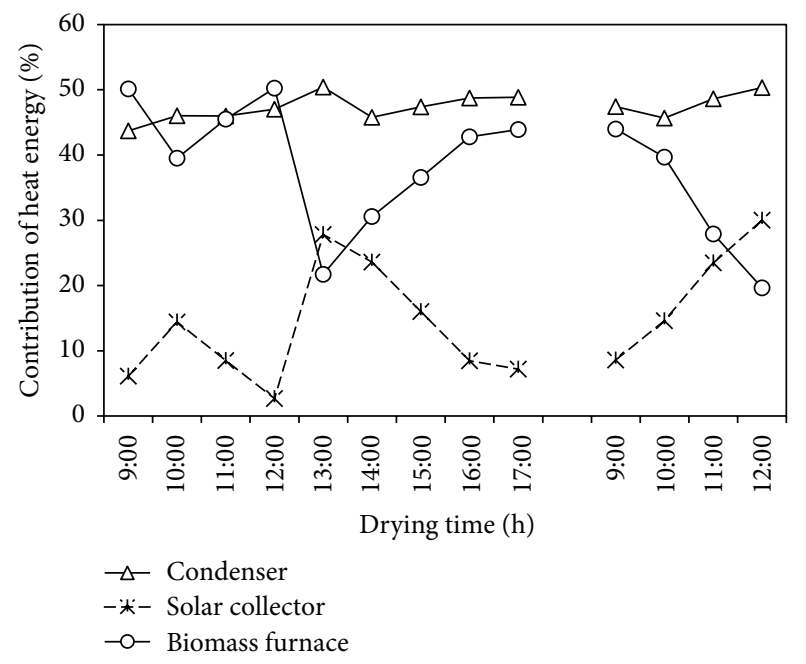

FIGURE 19: The variation of the contribution of heat energy with drying time.

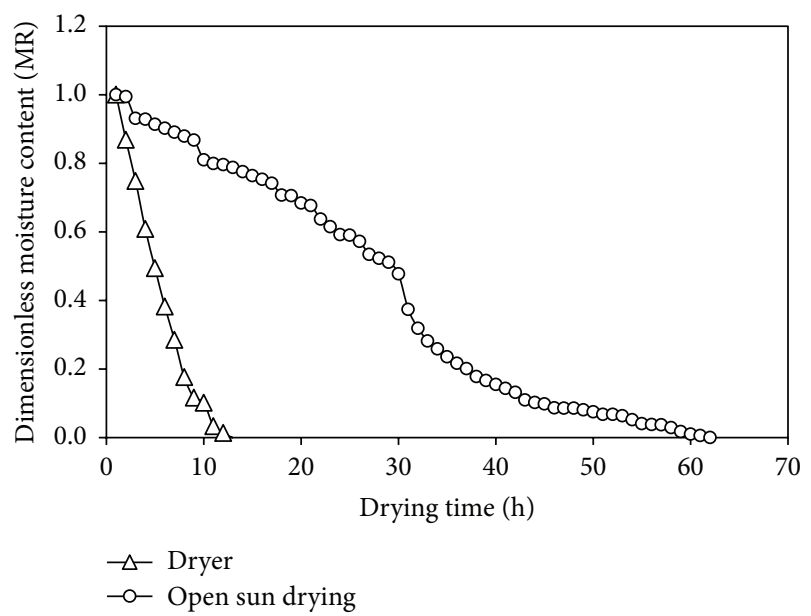

FIGURE 20: The variation of dimensionless moisture content data of dried red chilli in a solar assisted heat pump integrated with biomass furnace and open sun drying with drying time.

with biomass furnace and open sun drying with drying time are shown in Figure 20. The dimensionless moisture content of red chilli reduced exponentially as the drying time increased. Continuous decrease in dimensionless moisture content indicates that diffusion has governed the internal mass transfer. As seen from the figure the reduction of moisture content of red chilli dried using a solar assisted heat pump integrated with biomass furnace is faster than the open sun drying; this is because the air drying temperature is higher, and air drying relative humidity is lower than the open sun drying. At high air drying temperature and low relative humidity, the difference in partial vapor pressure between red chilli and the air drying is high; thereby the acceleration of moisture migration is also high.

The dimensionless moisture content data of dried red chilli in a solar assisted heat pump integrated with biomass furnace and open sun drying were fitted in three drying 


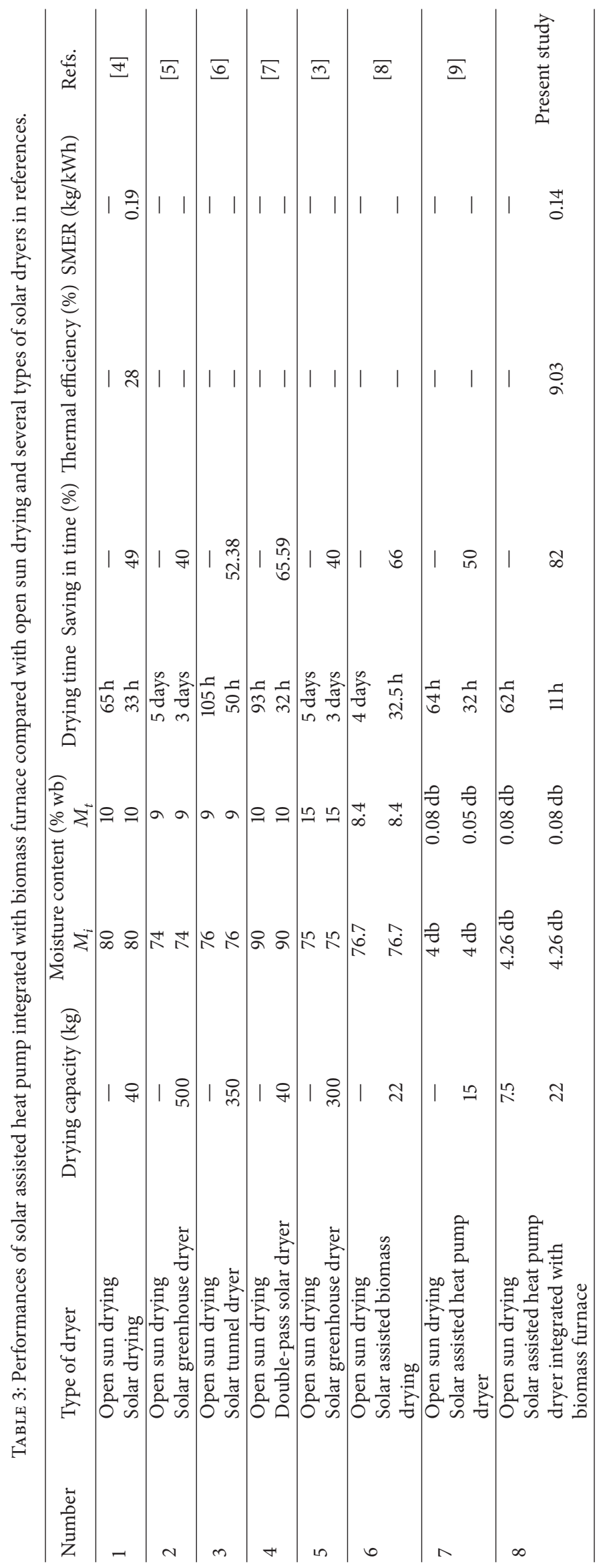


TABLE 4: Statistical results mathematical modelling of drying curves.

\begin{tabular}{|c|c|c|c|c|c|}
\hline Model & Method of drying & Model coefficients and constants & $R^{2}$ & MBE & RMSE \\
\hline \multirow{2}{*}{ Newton } & Open sun drying & $k=0.0560$ & 0.7235 & 0.0376 & 0.1939 \\
\hline & Dryer & $k=0.2900$ & 0.8687 & 0.0137 & 0.1172 \\
\hline \multirow{2}{*}{ Henderson and Pabis } & Open sun drying & $k=0.0756 ; a=2.2246$ & 0.7946 & 0.0662 & 0.2574 \\
\hline & Dryer & $k=0.3576 ; a=1.6335$ & 0.9093 & 0.0037 & 0.0609 \\
\hline \multirow{2}{*}{ Page } & Open sun drying & $k=1.4873 ; n=0.0072$ & 0.9410 & 0.0051 & 0.0713 \\
\hline & Dryer & $\mathrm{k}=1.4080 ; \mathrm{n}=0.1140$ & 0.9822 & 0.0008 & 0.0278 \\
\hline
\end{tabular}

models such as the Newton model, Henderson-Pabis model, and the Page model. The regression constant, the values of the coefficient of determination $\left(R^{2}\right)$, the mean bias error (MBE), and the root mean-square error (RMSE) for these drying models are given in Table 4 . It can be observed in Table 3 that the Page model fitted best with the experimental data compared with the Newton and Henderson-Pabis drying models; this is because the value of $R^{2}$ is higher, and MBE and RMSE are lower than the Newton and Henderson-Pabis drying models. Page model for drying of red chilli using a solar assisted heat pump integrated with biomass furnace gave $R^{2}=0.9822$, MBE $=0.0008$, and $\mathrm{RMSE}=0.0278$. Meanwhile, Page model for drying of red chilli using open sun drying gave $R^{2}=0.9410, \mathrm{MBE}=0.0051$, and $\mathrm{RMSE}=$ 0.0713 .

The variations of dimensionless moisture content data of dried red chilli in a solar assisted heat pump integrated with biomass furnace and open sun drying with drying time fitted with the Page model are shown in Figure 21. It can be seen from this that there was a better fit between experimental data and predicted dimensionless moisture ratios.

The variation of drying rate with dimensionless moisture content of dried red chilli in a solar assisted heat pump integrated with biomass furnace is shown in Figure 22. Drying of red chilli occurred in falling rate period; constant drying rate period was not observed. During the falling rate period, the drying rate decreased continuously with decreasing dimensionless moisture content and increasing drying time. These are similar results as the observation of earlier researchers [7, 31]. From the curve of drying rate with dimensionless moisture content of red chillies, the regression equation was created as

$$
\mathrm{DR}=2.4456+0.5449 \ln (\mathrm{MR}) ; \quad R^{2}=0.9267 .
$$

\section{Conclusion}

The performance of a solar assisted heat pump dryer integrated with biomass furnace has been designed and evaluated for drying red chillies, and drying kinetics of red chillies were evaluated. The averages of the solar collector efficiency, COP of the heat pump, and the efficiency of biomass furnace were estimated to be about $35.1 \%, 3.84$, and $30.7 \%$, respectively. The red chillies were dried from $22 \mathrm{~kg}$ with moisture content of $4.26 \mathrm{db}$ to moisture content of $0.08 \mathrm{db}$ which needed 11 hours, with the average drying chamber temperature, drying chamber relative humidity, and an air mass flow rate of

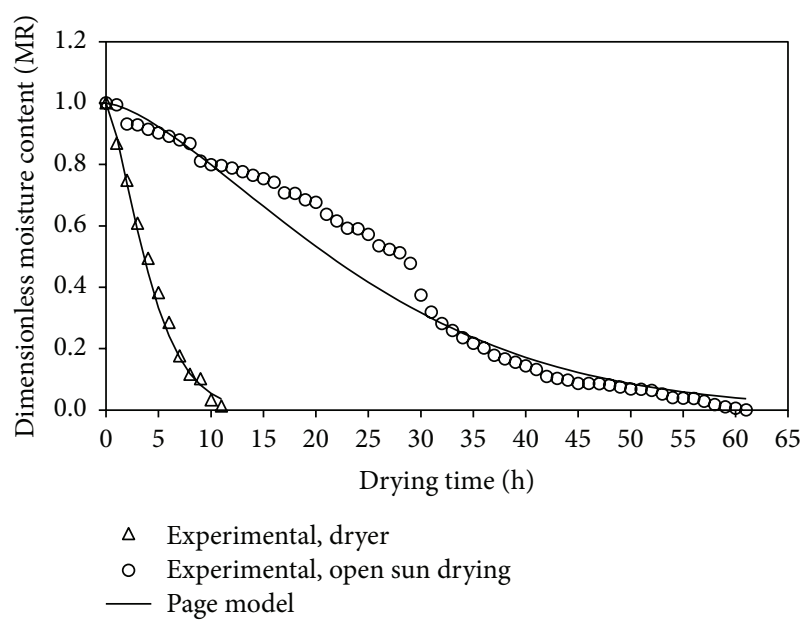

FIGURE 21: The variation of dimensionless moisture content data of dried red chilli in a solar assisted heat pump integrated with biomass furnace and open sun drying and Page model with drying time.

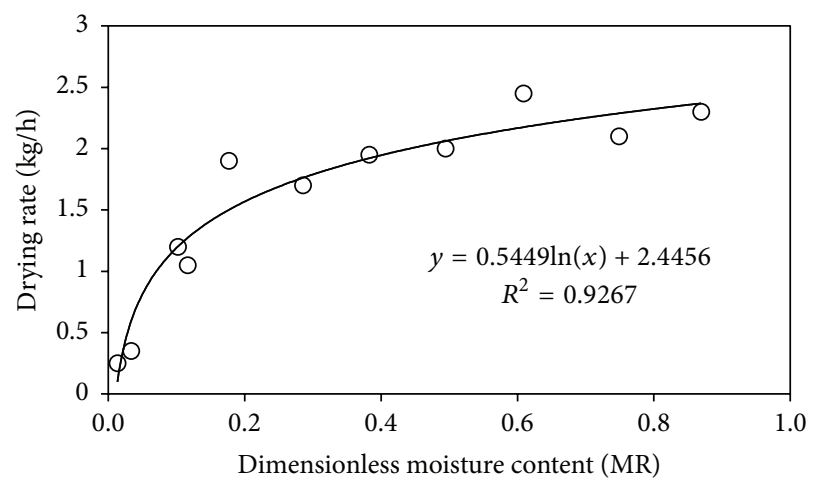

FIGURE 22: The variation of drying rate with dimensionless moisture content of dried red chilli in a solar assisted heat pump integrated with biomass furnace.

$70.5^{\circ} \mathrm{C}, 10.1 \%$, and $0.124 \mathrm{kgs}^{-1}$, respectively, while the open sun drying needed 62 hours. Compared to open sun drying, this dryer yielded a $82 \%$ saving in drying time. The drying rate was estimated in average to be about $1.57 \mathrm{~kg} / \mathrm{h}$, while the specific moisture extraction rate and thermal efficiency of the dryer were estimated in average to be about $0.14 \mathrm{~kg} / \mathrm{kWh}$ and $9.03 \%$, respectively. The contributions of heat energy by the collector, condenser, and biomass furnace were estimated in 
average to be about $14.74 \%, 47.39 \%$, and $37.87 \%$, respectively. The biomass fuel (coconut shell charcoal) was needed during drying of about $11 \mathrm{~kg}$. Drying of red chilli occurred in falling rate period; constant drying rate period was not observed. The Page model fitted best with the experimental data compared with the Newton and Henderson-Pabis drying models. It resulted in the highest $R^{2}$ and the lowest MBE and RMSE. Result shows that this dryer is capable of drying red chillies quickly because of the high drying rate.

\section{Nomenclature}

\begin{tabular}{|c|c|}
\hline$A_{C}:$ & Area of collector $\left(\mathrm{m}^{2}\right)$ \\
\hline $\cos \varphi$ & Power factor \\
\hline$a:$ & Drying constant \\
\hline MBE: & Mean bias error \\
\hline$C_{P \text { air }}:$ & Specific heat of air $\left(\mathrm{Jkg}^{-1} \mathrm{C}^{-1}\right)$ \\
\hline$I:$ & Line current (ampere) \\
\hline$I_{T}:$ & Solar radiation $\left(\mathrm{Wm}^{-2}\right)$ \\
\hline$\dot{m}_{\text {air }}:$ & Air mass flow rate $(\mathrm{kg} / \mathrm{s})$ \\
\hline$\dot{m}_{\mathrm{bmf}}:$ & Biomass fuel consumption rate $(\mathrm{kg} / \mathrm{h})$ \\
\hline$\dot{m}_{\text {water }}:$ & Mass of water evaporation rate $(\mathrm{kg} / \mathrm{h})$ \\
\hline$m_{\text {wetrc }}:$ & Mass of wet red chillies (kg) \\
\hline$E_{s}:$ & $\begin{array}{l}\text { Energy incident in the plane of the solar } \\
\text { collector }(\mathrm{kW})\end{array}$ \\
\hline$V:$ & Line voltage (Volt) \\
\hline $\mathrm{CV}_{\mathrm{bmf}}$ : & Caloric value of biomass fuel $(\mathrm{kcal} / \mathrm{kg})$ \\
\hline$E_{\mathrm{bl}}:$ & Electrical energy consumed by blower (kW) \\
\hline$E_{\mathrm{bmf}}:$ & $\begin{array}{l}\text { Heat energy generated by the combustion of } \\
\text { biomass fuel }(\mathrm{kW})\end{array}$ \\
\hline$E_{\text {comp }}:$ & $\begin{array}{l}\text { Electrical energy consumed by compressor } \\
(\mathrm{kW})\end{array}$ \\
\hline HEC: & Percentage of heat energy contribution (\%) \\
\hline$H_{\text {fg }}:$ & Latent heat of vaporization of water $(\mathrm{J} / \mathrm{kg})$ \\
\hline$m_{d}:$ & Mass of bone dry of the red chillies \\
\hline$M_{e}:$ & Equilibrium moisture content on dry basis \\
\hline$M_{f}:$ & Final moisture content on wet basis (\%) \\
\hline$M_{i}:$ & Initial moisture content on wet basis (\%) \\
\hline$M_{o}:$ & Initial moisture content on dry basis \\
\hline$M_{t}:$ & Moisture content at any time on dry basis \\
\hline$m_{w}:$ & Mass of water of the red chillies $(\mathrm{kg})$ \\
\hline$N:$ & Number of observations \\
\hline$n:$ & Drying constant \\
\hline$Q_{u}:$ & Useful energy (kW) \\
\hline$R^{2}:$ & Coefficient of determination \\
\hline RMSE: & Root mean-square error \\
\hline$T:$ & Temperature $\left({ }^{\circ} \mathrm{C}\right)$. \\
\hline
\end{tabular}

Subscripts

bf: Biomass furnace

coll: Solar collector

comp: Compressor

cond: Condenser

hp: Heat pump

$i$ : $\quad$ Inlet

o: $\quad$ Outlet.

\section{Competing Interests}

The author declared that this current paper has no competing interests.

\section{Acknowledgments}

The author would like to thank to Higher Education Directorate of Education and Cultural Ministry of Indonesia (DIKTI) for research funding through the Hibah Bersaing Research Grant scheme.

\section{References}

[1] Statistical Yearbook of Indonesia, 2015.

[2] A. Fudholi, M. Y. Othman, M. H. Ruslan, and K. Sopian, "Drying of malaysian Capsicum annuum L. (Red Chili) dried by open and solar drying," International Journal of Photoenergy, vol. 2013, Article ID 167895, 9 pages, 2013.

[3] S. Janjai, P. Intawee, J. Kaewkiew, C. Sritus, and V. Khamvongsa, "A large-scale solar greenhouse dryer using polycarbonate cover: modeling and testing in a tropical environment of Lao People's Democratic Republic," Renewable Energy, vol. 36, no. 3, pp. 1053-1062, 2011.

[4] A. Fudholi, K. Sopian, M. H. Yazdi, M. H. Ruslan, M. Gabbasa, and H. A. Kazem, "Performance analysis of solar drying system for red chili," Solar Energy, vol. 99, pp. 47-54, 2014.

[5] J. Kaewkiew, S. Nabneaan, and S. Janjai, "Experimental investigation of the performance of a large-scale greenhouse type solar dryer for drying chilli in Thailand," Procedia Engineering, vol. 32, pp. 433-439, 2012.

[6] V. Palled, S. R. Desai, and M. Anantachar, "Performance evaluation of solar tunnel dryer for chilly drying," Karnataka Journal of Agricultural Sciences, vol. 25, no. 4, pp. 472-474, 2012.

[7] J. Banout, P. Ehl, J. Havlik, B. Lojka, Z. Polesny, and V. Verner, "Design and performance evaluation of a Double-pass solar drier for drying of red chilli (Capsicum annum L.)," Solar Energy, vol. 85, no. 3, pp. 506-515, 2011.

[8] A. M. Leon and S. Kumar, "Design and performance evaluation of a solar-assisted biomass drying system with thermal storage," Drying Technology, vol. 26, no. 7, pp. 936-947, 2008.

[9] A. Artnaseaw, S. Theerakulpisut, and C. Benjapiyaporn, "Development of a vacuum heat pump dryer for drying chilli," Biosystems Engineering, vol. 105, no. 1, pp. 130-138, 2010.

[10] M. M. S. Dezfouli, S. Mat, M. H. Ruslan, and K. Sopian, "Evaluation of drying chili by two methods: solar assisted heat pump dryer and open sun drying," in Proceeding of the 1st International Conference on Environmental Informatics (ENINF '13), pp. 112-116, Kuala Lumpur, Malaysia, 2013.

[11] N. A. Handayani and D. Ariyanti, "Potency of solar energy application in Indonesia," International Journal of Renewable Energy Development, vol. 1, no. 2, pp. 33-38, 2012.

[12] B. Prastowo, "Biomass resource in Indonesia: Indonesia's solid biomass energy potential," in Proceedings of the IndonesiaGerman Workshop and Seminar, pp. 1-15, Institute Technology of Bandung, September 2011.

[13] B. M. A. Amer, M. A. Hossain, and K. Gottschalk, "Design and performance evaluation of a new hybrid solar dryer for banana," Energy Conversion and Management, vol. 51, no. 4, pp. 813-820, 2010. 
[14] M. N. A. Hawlader, S. K. Chou, and M. Z. Ullah, "The performance of a solar assisted heat pump water heating system," Applied Thermal Engineering, vol. 21, no. 10, pp. 1049-1065, 2001.

[15] M. N. Ibrahim, M. S. H. Sarker, A. B. Azizn, and S. P. Mohd, "Drying performance and overall energy requisite of industrial inclined bed paddy drying in Malaysia," Journal of Engineering Science and Technology, vol. 9, no. 3, pp. 398-409, 2014.

[16] T. Swasdisevi, S. Soponronnarit, A. Shujinda, S. Wetchacama, and V. Thepent, "Rice husk furnace for fluidized bed paddy dryer," in Proceeding of the 2nd Asean Renewable Energy Conference, pp. 603-612, Puket, Thailand, 1997.

[17] A. Triyono, Skripsi: Karakteristik Briket Arang Dari Campuran Serbuk Gergajian Kayu Afrika Dan Sengon Dengan Penambahan Tempurung Kelapa, Fakultas Kehutanan, Institut Pertanian Bogor, Bogor, Indonesia, 2006.

[18] N. Srisittipokakun, K. Kirdsiri, and J. Kaewkhao, "Solar drying of andrographis paniculata using a parabolic-shaped solar tunnel dryer," Procedia Engineering, vol. 32, pp. 839-846, 2012.

[19] M. N. A. Hawlader and K. A. Jahangeer, "Solar heat pump drying and water heating in the tropics," Solar Energy, vol. 80, no. 5, pp. 492-499, 2006.

[20] V. Shanmugam and E. Natarajan, "Experimental study of regenerative desiccant integrated solar dryer with and without reflective mirror," Applied Thermal Engineering, vol. 27, no. 8-9, pp. 1543-1551, 2007.

[21] K. Sacilik, A. K. Elicin, and G. Unal, "Drying kinetics of Üryani plum in a convective hot-air dryer," Journal of Food Engineering, vol. 76, no. 3, pp. 362-368, 2006.

[22] E. K. Akpinar, "Drying of mint leaves in a solar dryer and under open sun: modelling, performance analyses," Energy Conversion and Management, vol. 51, no. 12, pp. 2407-2418, 2010.

[23] R. K. Goyal, A. R. P. Kingsly, M. R. Manikantan, and S. M. Ilyas, "Mathematical modelling of thin layer drying kinetics of plum in a tunnel dryer," Journal of Food Engineering, vol. 79, no. 1, pp. 176-180, 2007.

[24] M. Aktaş, I. Ceylan, and S. Yilmaz, "Determination of drying characteristics of apples in a heat pump and solar dryer," Desalination, vol. 238, no. 1-3, pp. 266-275, 2009.

[25] K. Sacilik, R. Keskin, and A. K. Elicin, "Mathematical modelling of solar tunnel drying of thin layer organic tomato," Journal of Food Engineering, vol. 73, no. 3, pp. 231-238, 2006.

[26] I. Ceylan, M. Aktaş, and H. Doğan, "Mathematical modeling of drying characteristics of tropical fruits," Applied Thermal Engineering, vol. 27, no. 11-12, pp. 1931-1936, 2007.

[27] S. Arora, S. Bharti, and V. K. Sehgal, "Convective drying kinetics of red chillies," Drying Technology, vol. 24, no. 2, pp. 189-193, 2006.

[28] S. Kaleemullah and R. Kailappan, "Drying kinetics of red chillies in a rotary dryer," Biosystems Engineering, vol. 92, no. 1, pp. 15-23, 2005.

[29] S. Şevik, "Experimental investigation of a new design solar-heat pump dryer under the different climatic conditions and drying behavior of selected products," Solar Energy, vol. 105, pp. 190205, 2014.

[30] E. K. Akpinar and Y. Bicer, "Mathematical modelling of thin layer drying process of long green pepper in solar dryer and under open sun," Energy Conversion and Management, vol. 49, no. 6, pp. 1367-1375, 2008.

[31] S. Kaleemullah and R. Kailappan, "Modelling of thin-layer drying kinetics of red chillies," Journal of Food Engineering, vol. 76, no. 4, pp. 531-537, 2006. 

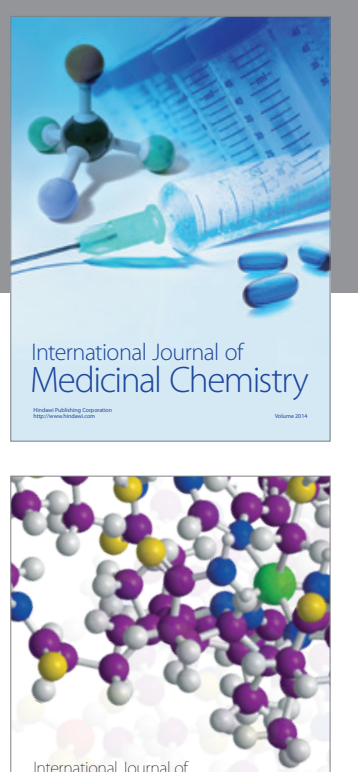

Carbohydrate Chemistry

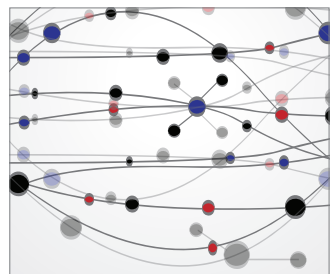

The Scientific World Journal
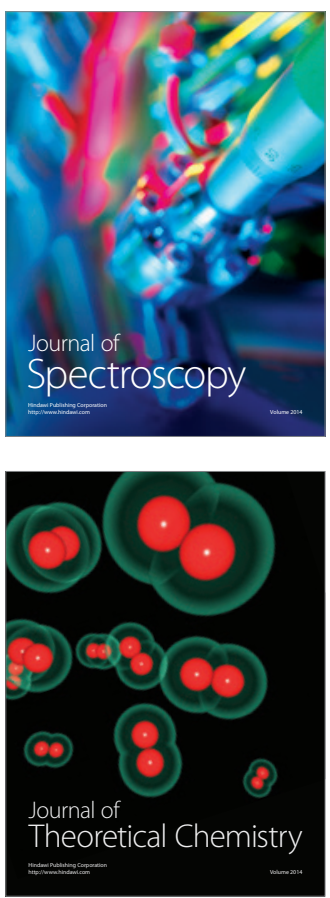
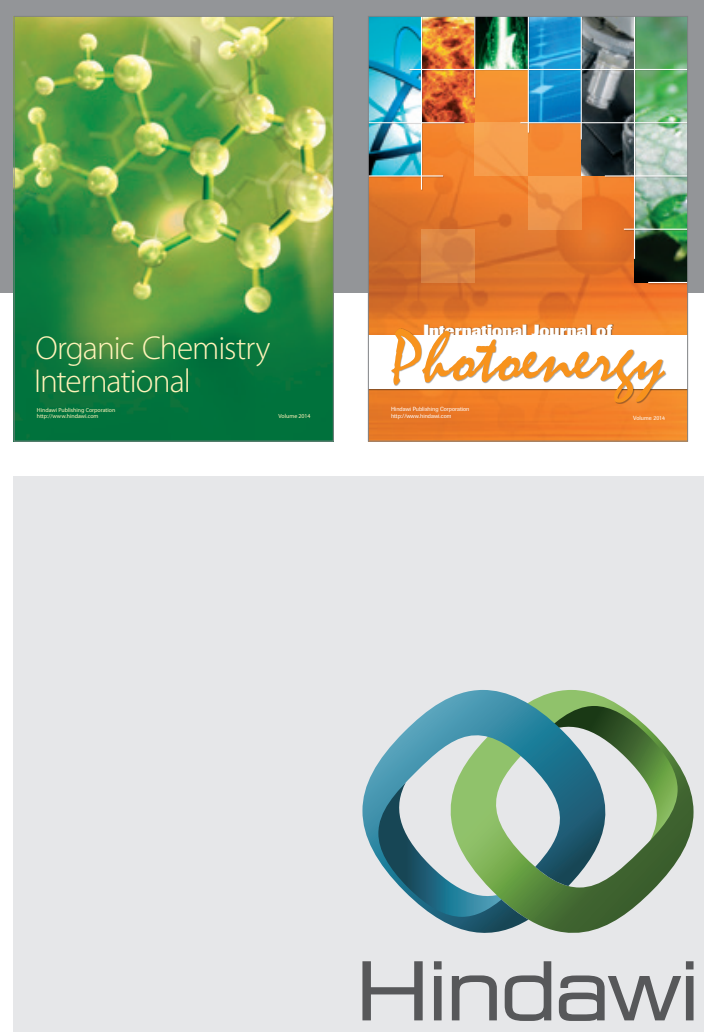

Submit your manuscripts at

http://www.hindawi.com

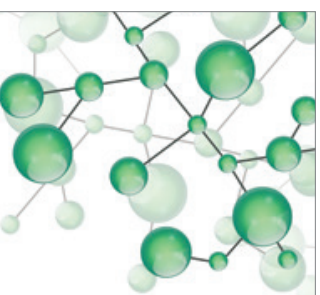

International Journal of

Inorganic Chemistry

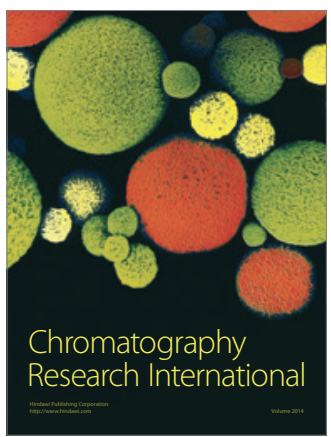

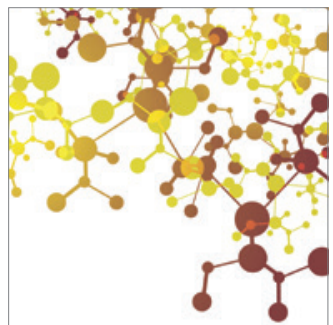

Applied Chemistry
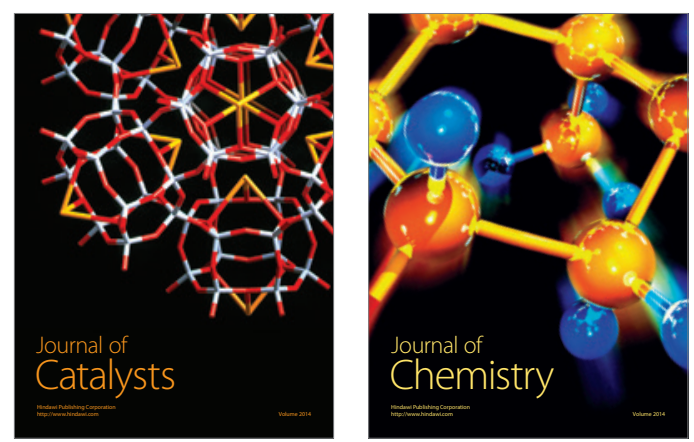
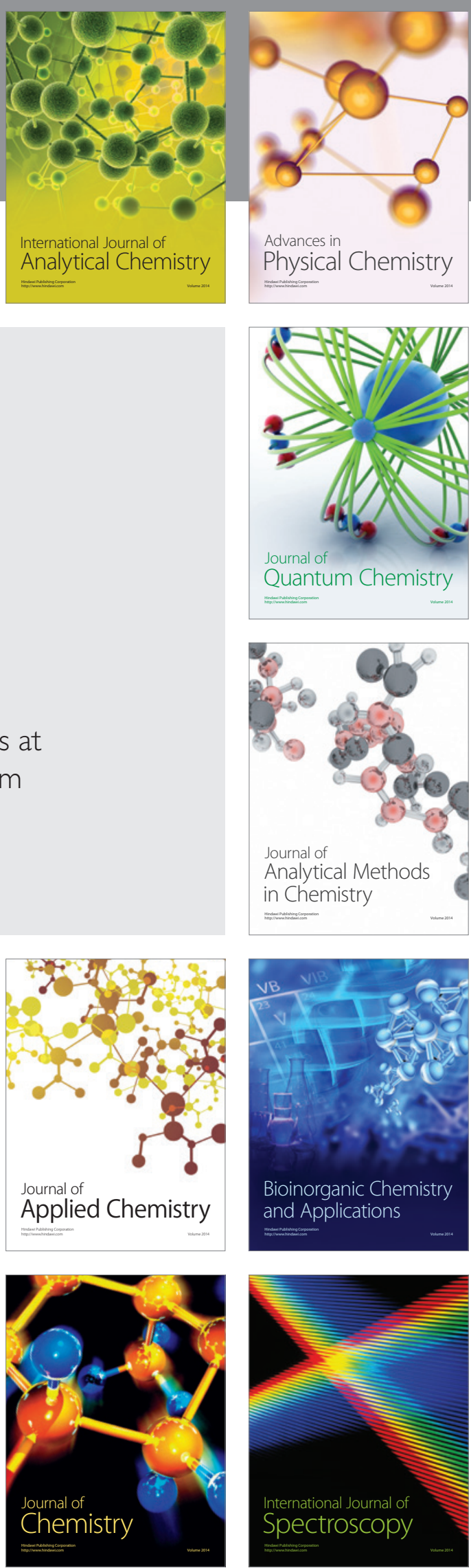